\title{
EFL TEACHERS' PERCEPTIONS ON THE CHANGES IN THE 2013 CURRICULUM AT JUNIOR HIGH SCHOOLS IN MARTAPURA
}

\author{
Devie Dian Nisrina \\ Islamic University of Kalimantan \\ E-mail: deviediann@gmail.com
}

\begin{abstract}
This research is to examine the extent of the EFL teachers' perceive and describe their perceptions on the changes in the 2013 curriculum at junior high schools in Martapura. This research uses a survey design with techniques used to collect data are questionnaires and documentation. In this research, random simple sampling is used and the number of respondents are 17 EFL teachers at junior high schools in Martapura. The result of this research has found that EFL teachers' indicates positive about the 2013 curriculum. The extent of the EFL teachers' perceive on the changes in the 2013 curriculum in the highest percentage is EFL teachers' perceive in learning resources and education facilities that have $92,4 \%$, the medium percentage is student centered learning that have $83,5 \%$, and the low percentage is evaluation and assessment that have $76,8 \%$. Appropriate with the low percentage in evaluation and assessment, it was also found that EFL teachers' has perception that they still lack with the assessment system in the 2013 curriculum.
\end{abstract}

Keywords: The 2013 Curriculum; EFL Teachers' Perceptions

\section{Introduction}

Curriculum means all the learning which is planned or guided by the school, whether it is carried in groups or individually, inside or outside the school (Taylor: 1966). It plays an important role in organizing, directing, and guiding the learning activities at school.

In Indonesia, curriculum has changed several times. During the last 40 years, Indonesia has undergone six changes in the curriculum for primary and secondary school education, namely the 1975 Curriculum, 1984 Curriculum, 1994 Curriculum, 2004 Curriculum, 2006 Curriculum, and 2013 Curriculum (Hamied, 2014).

In 2013, the government introduced new curriculum. The 2013 curriculum is an integrated curriculum as a concept can be said as a system or learning approach that involves several disciplines to provide a meaningful and comprehensive experience to learners. This curriculum has four aspects of assessment, namely aspects of knowledge, skills, attitude and behavior.

In the beginning, the idea of the 2013 curriculum received many attentions and responses from a number of groups, which basically feel the turmoil of the renewal movement in the field 
of education. The implementation of the 2013 curriculum certainly found a variety of obstacles, such as the advancement of science, technology, and cultural arts as well as changes of society in each different region, teachers lack direction regarding the changes of the curriculum and also lack the time to learn the new curriculum, so that many teachers who re-use KTSP because it is more easily understood by the teachers. But, not all teachers stop using the 2013 curriculum, because there are some teachers instead feels more suitable and easier to use the 2013 curriculum. Based on this, every teacher, including EFL teachers has an individual perceptions on the changes in the 2013 curriculum.

Perception itself, according to Sarwono, S.W (1983:89) is a someones' ability for organize some observation, the ability such as ability to distinguish, group and focus something that found. Meanwhile, according to Robbins (1996: 124), perception can be defined as a process by which individuals organise and interpret their sensory impressions in order to give meaning to their environment.

\section{Method}

This research used quantitative method. Aliaga \& Gunderson (2002) describe it as explaining a phenomenon by collecting quantitative (numerical) data that are analysed using mathematically based methods such as statistics. In this research, the researcher used a survey design. According to Hughes (1990:76), survey is a method of research by using questionnaires as instrument to collecting data.

The location of this research was conducted at junior high schools in Martapura on July 2018. In this research, the population is all EFL teachers at junior high schools in Martapura, and collecting data used simple random sampling. The sample of this research are $17 \mathrm{EFL}$ teachers.

The techniques of collecting data used in this research are questionnaire and documentation. The researcher used a mixed questionnaire. On the closed-ended item, there were 20 statements and the EFL teachers were asked to pick the answer "Strongly Agree, Agree, Neutral, Disagree, and Strongly Disagree". And there 5 questions in the open-ended item which the EFL teachers responded by writing their answer with their own words.

\section{Table 1}

Questionnaire Template

\begin{tabular}{|l|l|}
\hline $\begin{array}{l}\text { Demographic } \\
\text { information }\end{array}$ & Title of the questionnaire, identity of respondent \\
\hline $\begin{array}{l}\text { Closed-ended } \\
\text { items }\end{array}$ & 1. Likert scale items \\
\hline $\begin{array}{l}\text { Open-ended } \\
\text { items }\end{array}$ & 2. Short answer items \\
\hline
\end{tabular}


http://ojs.uniska-bjim.ac.id/index.php/EJB

E-ISSN 1513567470

October 2018, Vol 1 No.2

On the close-ended item there are 5 criteria for analyze data, namely:

Table 2

Question Scoring

\begin{tabular}{|l|c|}
\hline \multicolumn{1}{|c|}{ Answer } & Score \\
\hline Strongly Agree & 5 \\
\hline Agree & 4 \\
\hline Neutral & 3 \\
\hline Disagree & 2 \\
\hline Strongly Disagree & 1 \\
\hline
\end{tabular}

The data from questionnaire were computed to get the mean values and percentage. To interpret the mean score, the researcher adapted the interpreting data designed by Chaihiranwattana \& Nookua (2010) as shown in table 1.3 below:

\section{Table 3}

Interpretation of mean score of the EFL teachers' perceive

\begin{tabular}{|c|c|}
\hline Mean levels & Score Range \\
\hline Very Positive & $4,21-5,00$ \\
\hline Positive & $3,41-4,20$ \\
\hline Neutral & $2,61-3,40$ \\
\hline Negative & $1,81-2,60$ \\
\hline Very Negative & $1,00-1,80$ \\
\hline
\end{tabular}

While data collected from the open-ended item analyzed descriptively in order to get clear information of the data about teachers' perceptions on the changes in the 2013 curriculum.

\section{Finding}

There are six schools; SMP Negeri 1 Martapura, SMP Negeri 2 Martapura, SMP Negeri 3 Martapura, SMP Negeri 4 Martapura, SMP Negeri 1 Martapura Timur, and SMP Negeri 2 Martapura Timur. The research has been conducted on July 2018. 
A. The Extent of the EFL Teachers' Perceive on the Changes in the 2013 Curriculum

In order to identify the type of the extent of the EFL teachers' perceive on the changes in the 2013 curriculum, the teachers were asked to 20-items questionnaire in 5 components on the closed-ended item.

\section{Table 4}

EFL Teachers' Perceive on the Changes in the 2013 Curriculum

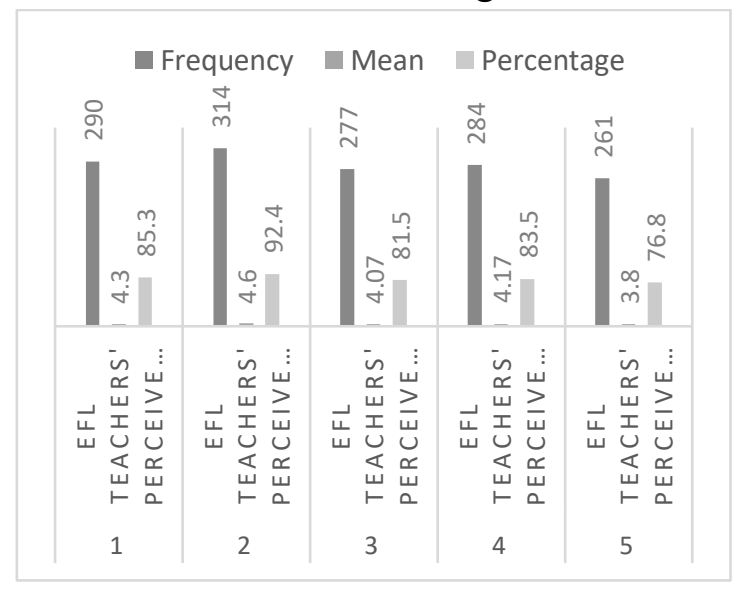

According to Table 1.4 above showed the first component EFL teachers' perceive on policy in the 2013 curriculum that have mean score 4,3 (85,3\%). The second component EFL teachers' perceive in learning resources and education facilities that have mean score 4,6 $(92,4 \%)$. The third component EFL teachers' perceive in method and strategies in teaching and learning that have mean score 4,07 $(81,5 \%)$. The fourth component EFL teachers' perceive in student centered learning that have mean score 4,17 (83,5\%). And the last component EFL teachers' perceive in evaluation and assessment have mean score 3,8 $(76,8 \%)$. That means the majority of all components showed mean score above 3,41 , which indicates a positive about the statements.

B. The Perceptions of the EFL Teachers on the Changes in the 2013 Curriculum

The perception of EFL teachers' on the changes in the 2013 curriculum described from the result of questionnaire in open-ended item. The responses varied. Some teachers have their own perceptions.

The first question to these respondents: is the 2013 curriculum has been answer for the problem of education at this time?

[Y2] Bila bisa dilaksanakan dengan baik dengan sarana dan prasarana yang baik bisa menjawab pendidikan yang berkarakter bagi anak. 


\section{Intensive Journal}

http://ojs.uniska-bjm.ac.id/index.php/EJB

E-ISSN 1513567470

October 2018, Vol 1 No.2

The second question: what is the challenge and opportunity in implementation of the 2013 curriculum on the English subject?

[FH]-Guru Bahasa Inggris sangat ditantang untuk bisa menjadi fasilitator belajar yang baik.

-Kurikulum 2013 memiliki peluang yang baik untuk diterapkan pada mata pelajaran Bahasa Inggris karena adanya keluwesan opsi metode yang disediakan.

The third question: is the lesson plan format which designed by ministry can help and ease to comprehend by teachers?

[HS] Ya, karena format RPP sudah sistematis sesuai dengan proses belajar mengajar.

The fourth question: is the scientific approach of the 2013 curriculum easy to do and does not give burden to the teachers in preparation aspect?

[WS] Tidak, karena pendekatan PBM sudah ilmiah sejak kurikulum terdahulu hanya saja baru kali ini saja di sebut pendekatan ilmiah.

The last question: is the assessment system of the 2013 curriculum easy to understand by teachers so it can help the process in students assessment?

[CMR] Sistem penilaian kurikulum 2013 dirasa cukup rumit dan membingungkan serta memakan banyak waktu dan usaha dalam pelaksanaannya.

\section{Discussion}

The finding from closed-ended questionnaire about the extent of the EFL teachers' perceive on the changes in the 2013 curriculum was indicates a good understanding on the extent of the EFL teachers' perceive on the changes in the 2013 curriculum with the highest percentage is EFL teachers' perceive in learning resources and education facilities that have $92,4 \%$. Next, EFL teachers' perceive in student centered learning was at medium percentage that have $83,5 \%$. And the low percentage is EFL teachers' perceive in evaluation and assessment that have $76,8 \%$.

From the data collected using an open-ended questionnaire about EFL teachers' perceptions on the changes in the 2013 curriculum found that a majority of EFL teachers at junior high schools in Martapura had a positive perceptions as seen from five question was given. However, on the question of assessment, it seems some EFL teachers still lack by the assessment system in the 2013 curriculum.

Thus, this research revealed that majority of EFL teachers in junior high schools in Martapura indicates a positive on the changes in the 2013 curriculum in English subject.

\section{Conclusion}

The changes of the curriculum to the 2013 curriculum makes EFL teachers at junior high schools in Martapura face challenges in implementing the new curriculum. Result of this 


\title{
Intensive Journal
}

\author{
http://ojs.uniska-bjm.ac.id/index.php/EJB \\ E-ISSN 1513567470 \\ October 2018, Vol 1 No.2
}

research which indicates a positive on the changes in the 2013 curriculum with the highest percentage is EFL teachers' perceive in learning resources and education facilities that have 92,4\%, EFL teachers' perceive in student centered learning was at medium percentage that have $83,5 \%$, and the low percentage is EFL teachers' perceive in evaluation and assessment that have 76,8\%. Appropriate to the lowest percentage, from the data collected using an openended questionnaire was also found that some of EFL teachers at junior high schools in Martapura had low knowledge about the authentic assessment which is considered too many and complicated.

\section{Suggestion}

From the conclusions above, the researcher has recommendation as follow, the government should provide extra support to EFL teachers by providing them with extra training, especially in terms of assessment system in the 2013 curriculum. More workshop about assessment system in the 2013 curriculum are needed to equip the EFL teachers get more knowledge to be able to implementing authentic assessment better in the future. Finally, respect to the assessment, assessment system in the 2013 curriculum should to be simplified.

\section{Refferences}

Hamied, Fuad Abdul. (2014). Curriculum change: what does it mean to Indonesian TEFL?. In Handoyo Puji Widodo and Nugrahenny T. Zacharias (Eds.), Recent issues in English language education: challenges and directions (pp.13-37). Surakarta: Sebelas Maret University Press.

Nur, M. ., \& Madkur, A. (2014). Teachers' Voices on the 2013 Curriculum for English Instructional Activities. International Journal of English Education, 1(2), 119-134.

Patankar, Dr. P \& Jadhav, Megha. (2013). ROLE OF TEACHERS' IN CURRICULUM DEVELOPMENT FOR TEACHER EDUCATION.

Rumahlatu, Dominggus, et al. An Analysis of the Readiness and Implementation of 2013 Curriculum in The West Part of Seram District, Maluku Province, Indonesia. Vol. 11, no. 12, 2016, pp. 5662-75.

Stephen P. Robbins, 1996. Perilaku Organisasi, Konsep, Kontroversi dan Aplikasi. Alih Bahasa : Hadyana Pujaatmaka. Edisi Keenam. Penerbit PT.Bhuana Ilmu Populer, Jakarta.

Zulhernanda, Windha. Teachers'Perceptions on Application Of 2013 Curriculum for Elementary School in Medan. no. c, 2018, pp. 62-66. 